\section{People's Park again: on the end and ends of public space}

\section{Don Mitchell}

Department of Geography, Syracuse University, USA
Environment and Planning $\mathrm{A}$ 2017, Vol. 49(3) 503-518 (C) The Author(s) 2015 Reprints and permissions: sagepub.co.uk/journalsPermissions.nav DOI: $10.1 \mid 77 / 03085$ I8X|56|I557 journals.sagepub.com/home/epn

@SAGE

\begin{abstract}
This paper uses three recent struggles over public space in California's East Bay (Berkeley and Oakland) to critically interrogate the 'end of public space' thesis. Developing a historical analysis of the discourse of the 'end of public space' over the past two and a half decades, the paper shows that dismissal of arguments about the end of public space both ignores the dialectical nature of the original interventions and comes at a real political and scholarly cost. The paper concludes that the tendency towards the end of public space in capitalism is closely related to the necessity for capitalism to produce abstract space. Both this tendency and this necessity are struggled over and contradictory, and it is out of these struggles and contradictions that actually-existing public space is produced.
\end{abstract}

\title{
Keywords
}

Public space, abstract space, urban geography

\section{Introduction}

Public space is a struggle. The purpose of this paper is to explore the nature of that struggle through three case studies from Oakland and Berkeley, California: Occupy Oakland; a Berkeley ballot initiative to impose 'sit-lie' restrictions on city streets; and continuing controversies over the control and use of Berkeley's People's Park. Through these cases I will make two initial claims. First, the question of the 'end of public space', originally forcefully raised in the urban literature at the beginning of the 1990s, has not gone away. While critics have rightly argued that the ideology of public space is problematic [because it can be so easily co-opted by those who seek to exclude 'undesirable' people from public space (Belina, 2011/12)], such arguments fail to take into account actual spaces - the struggle over the structuring, control, and use of actually-existing urban spaces. Urban public spaces remain sites of significant social struggle as well as sites over which struggle is engaged. Second, focusing on public space as a contested site indicates the need for a careful appraisal of the ends of public space: how public spaces are deployed socially, strategically, ideologically, as well as how they are used by myriad publics - the ends to which they are put.

\footnotetext{
Corresponding author:

Don Mitchell, Department of Geography, Syracuse University, 144 Eggers Hall, Syracuse, NY I3244, USA.

Email: dmmitc0I@maxwell.syr.edu
} 
These two initial claims, which emerge from the analysis of the three California struggles, yield a third argument. If we want to understand the dialectic between the ongoing end of public space and public space's myriad ends, then we need to understand the tendency and necessity within capitalism for the production of abstract space, the forces - or really, the work - that seeks to make that tendency a reality, and the forces that push against that tendency and thus might interrupt its necessary production. In so doing we can begin to better grasp the dynamics structuring publicly accessible space in the city.

Before turning to the case studies and the argument about abstract space that develops out of them, I first provide a brief survey of the rise of public space research and especially of the 'end of public space' thesis, since by doing so the stage can be set, theoretically as well as historically, for understanding the three California struggles and their larger meaning; especially it provides a foundation for understanding public space's position within the capitalist tendency towards the production of abstract space.

\section{The end of public space?}

Twenty-five years ago the importance of public space to urban political economy, city life, and the structure of capitalist cities more generally, was just beginning to be recognized. Before the late 1980s, public space was largely understood to be a design issue (Whyte, 1980, 1988) or perhaps a policing one (Wilson and Kelling, 1982). However, two books were published at the outset of the 1990s that catalyzed new, sharply critical, and eventually wide-ranging research on the role of public space in making more or less just cities: Mike Davis's City of Quartz: Excavating the Future in Los Angeles (1990) and Michael Sorkin's edited Variations on a Theme Park: The New American City and the End of Public Space (1992). In powerful prose and with striking images, Davis examined how control over space was being effected (and to what ends) in Los Angeles. Transformations in public space were at the heart of Davis's analysis: private encroachment (by capital, homeowners, business associations, etc) into the public realm were remaking the city as a violent frontier of capital accumulation. This was a complex and contradictory process, and it was one that was set in a context of a city whose ethnic profile was rapidly changing. Public space was the space where the contradictions and changes were fought out. And it was, at least downtown, a space where the forces of a narrowly prescribed 'order' seemed to be winning out. Private policing, 'bum-proof' benches and other antihomeless tactics, Business Improvement Districts, hyperdefensive space: all these seemed to indicate the end of the public city if not the end of publicly accessible space as such.

The authors in Variations on a Theme Park (including Davis, who reprised an argument from City of Quartz) picked up on this theme in various ways: examining the gentrification frontier as a violent frontier, the mall and Disney World as the model for downtown, the rise of the 'analogous' city of skybridges and tunnels, and the commodification of space and history attendant upon the creation of festival marketplaces. Most striking in the book, though, is the degree to which public space is not theorized; rather an image or shared understanding of what public space is, is mostly assumed. The image seems to be one of open or relatively open access, of little capital control over the full functioning of the space, of light policing. Public space is primarily defined by what it is not: private space. The end of public space in the American city is its privatization.

Both these books seemed to name something crucial happening in American cities (and by extension other developed-world cities) at the end of the 1980s. Together with David Harvey's (1987, 1989a, 1989b) seminal arguments about the rise of the entrepreneurial city and Ed Soja's (1989) arguments about the postmodern city that in many ways ran 
parallel to (and provided a bit of inspiration for) Davis's arguments, these books helped set off a period of intense retheorizing of the city, of which the theorization and criticalhistorical analysis of public space was a central part. The degree of intensity of research after 1990 can be measured in the exponential growth of published work on public space. There was only a smattering of studies of public space in the geographical literature before 1990. In the 1970s sometimes as many as three articles, chapters, or books on public space would appear in the Anglophonic geographical literature in a year, many of them exploring public space in relation to phenomenology, but some analyzing public space in relation to Oscar Newman's (1972) notion of defensible space. ${ }^{1}$ But these tailed off, and between 1980 and 1988 there were never more than two pieces written on public spaces and in two years there were none. But then the drumbeat quickened. There were six in 1988, nine in 1989 and 1990, and sixteen in 1992 (in 1991 six were published). And then quickened again: twentytwo in 1993, twenty-nine in 1996, and forty in 1998. Public space was hot. And it remained hot. Searching in the Scopus database and using a quite restrictive definition, ${ }^{2}$ I identified twenty Anglophonic articles published by geographers or in geography journals for 2000, twenty-six for 2004, forty-five for 2008, and forty-nine for 2012.

There are many reasons for this sustained interest in public space. The agenda Davis, Sorkin, and others set, which reflected the rather stark and observable transformation of the city that marked the end of Keynesianism was and remains an important one. In what ways, they were asking, was the city being remade to reflect particular class interests, and what did that mean for living in and the use of the city by everyone else? What did it mean economically, socially, and politically? Who benefited from the seeming end of public space - a space representative of, and conducive to, the 'public' that had been created in the Keynesian era-as the city was reclaimed through redevelopment, gentrification, technical change, transformations in policing and law, and the reassertion of the primacy of private property? A concomitant question of just who constituted 'the public' (Marston, 1990) also seemed to be taking on added relevance as a new neoliberal order was being built in cities. On the ground, a resurgence of urban unrest, exemplified by the Los Angeles uprising in 1992 as well as any number of smaller skirmishes [the poles of which are perhaps best represented by, on the one hand, the Tompkins Square Park riot of 1988 (Smith, 1989) or the People's Park riot of 1991 (Mitchell, 1995), and on the other by the sort of race-conflict depicted in Spike Lee's Do The Right Thing (1989)] made it clear that public space had to be understood as both a space of conflict and a space essential to the creation and resolution of conflict.

By the time Davis was writing, the 'crisis' of homelessness, which many interpreted to be a crisis of public space, was into its second decade (Hopper, 2003). James Wilson and George Kelling's (1982) original 'broken windows' thesis was promulgated in large part as a defense against homeless people's use and occupation of public space, which they saw as necessarily detrimental to order in the city. Homeless people either directly or indirectly ruined, or led to the ruin, of public space, an argument echoed by any number of pundits and policy documents. A quite loud chorus developed in support of new 'quality of life' laws to govern homeless people's use of public space, and perhaps to remove them altogether. Yet homeless populations continued to expand and to seek refuge in parks, on sidewalks, in riverbank encampments, or elsewhere, either because no other shelter was available or because it was unsafe or because it was closed during daytime hours. Homeless people forced the question of public space: what it was for, who belonged in it and who did not, how it related to the shifting dynamics of property in the city, and so forth. As Jeremey Waldron (1991) famously argued, homeless people could only be - that is live as humans - to the degree they had access to public space. 
And not only homeless people required public space, so too did political people, and their public space - the space for organizing and protesting - also seemed to be shrinking if not disappearing altogether. Already at the 1984 Democratic National Convention in San Francisco (and probably much earlier), the regulation of protest in public space became a question of renewed urgency, both politically and academically, as urban authorities restricted protest to specially designated, and well out of the way, 'protest zones' denying activists the right to confront delegates head-on. This move was of a piece with a larger trend in protest policing. Scholars of protest — outside geography — had noted a shift in protest policing after the 1960s, from an 'escalation of force' strategy to a 'negotiated management' strategy (McPhail et al., 1998). Instead of beating protesters up, or otherwise basing policing on force, police - aided by transformations in law governing rights to assembly and speech - engaged in a dual strategy: the zoning of space for (peaceful) protest (outside of which protesting would be banned) and negotiation with protest organizers over the form of protest (including how arrests were to be handled). ${ }^{3}$ Both strategies eventually reworked the relationship between public space and politics, emphasizing public space as a space of control, limits, and, again, order (cf Staeheli and Mitchell, 2008). Such a transformation called into question the nature of public space in the construction of publicity, in the possibilities for (or against) the formation of a political public sphere as well as for (or against) political action. These possibilities seemed, for many in protest movements anyway, to be highly constrained. 'Order' seemed, in this realm as in the realm of homelessness, to be the order of the day.

Many in cities welcomed the new order of Order, especially as both crime and fear of crime increased during the 1980s and gentrification (as a specific form of capital circulation in the built environment) reopened inner cities for bourgeois settlement. Orderly public spaces were understood to be both necessary for urban development and an outcome of it. Public space had to be made safe for capital and new urbanites. Festival marketplaces and other forms of private-public space (such as New York's Privately-Owned Public Spaces-POPS - the 'bonus plazas' developers created in order to build higher and denser), dating from the 1960s but gaining popularity in the two decades that followed, were embraced by suburbanites, tourists, and new urbanites alike (Kayden, 2000; Kohn, 2004; Miller, 2007; Németh, 2009). They provided a new kind of public space, one in which fear of violence or the other was held at bay by private police forces and by the different ways private property owners (compared with city governments) could control access. New opportunities for sociability were thus opened (as old ones were closed down). Privately owned space became the place for urban encounter (Goss, 1996). If these new forms of sociability were mediated largely through commodity production, so much the better: controlled private-public spaces such as malls, festival marketplaces, and POPS were meant to be part of the new economic base of the city as manufacturing fled for the exurban fringe or overseas (Crilley, 1993; Harvey, 1989b).

Yet by the 1980 s, cities were realizing they could not rely solely on the production of privately owned public space for their economic well-being. New modes of control needed to be invented for all those other public spaces - streets and sidewalks, for example, or parks the contemporary city inherited from previous eras which were therefore structured and controlled according to different social sensibilities than seemed wise in the current moment - even as the fiscal crisis of the state (at all scales) reduced governments' capacities to order and regulate, much less maintain, public space. Conservancies and trusts, funded by wealthy private benefactors but chartered for the 'public good', as well as Business Improvement Districts funded by special taxes, rose to fill the void (Katz, 2006; Staeheli and Mitchell, 2008; Zukin, 1995). The construction, maintenance, and governance of public space were significantly privatized. 
Coming from a different direction (though certainly interwoven with trends so far outlined) the increased presence of women, gays, and minorities in public space-as workers in remade labor markets, as political actors, and as women, gays, and minorities - raised in new ways questions of who public space is for and what violence in public space was meant to contain. Women's, gays', and minorities' insistence on being present and visible in public space forced dominant society to confront its exclusions. Gay Pride parades and Take Back the Night events, to take just two examples dating from the 1970s, threw into question the dominant coding of public space (as heteronormative and/or masculinist). And the significant victories of the Civil Rights Movement, which dismantled many de jure exclusions to space (both public and private) for African Americans and other minorities forced dominant society to confront (and either shore up or dismantle) ongoing de facto exclusions.

To put all this another way: at the beginning of the 1990s, public space simultaneously seemed to be being closed down-brought to an end-through the pressurizing forces of order, quality-of-life and protest policing, and privatization (in its many guises) and opened up anew through the concerted struggles of 'new social movements' and the invention of new modes of urban sociability. If the end of public space seemed nigh, new ends for public space were being invented. Though not always interpreted in this way, Davis's and Sorkin's work made it clear that public space still was a struggle, and a struggle worth engaging. The tidal wave of work on public space that has since washed over geography and urban studies is mere confirmation of this fact.

In 1995 I sought to critically engage the 'end of public space' arguments and show why they mattered for understanding struggles for the democratic city (Mitchell, 1995). Analyzing the 1991 riot sparked by University of California (UC) plans to redevelop Berkeley's People's Park, I sought to show how what might be called actually-existing public space was produced through struggle, around two contrasting ideals of public space: public space as a space of politics and struggle, and public space as a space of retreat and leisure. Such ideals mapped onto questions of whether public space was a commons, constructed through practice (which was both customary and contentious) or a gift of the state and developers, as well as whether public space was the space for living, for forms of life, or a space only to visit, a space in which we are always only guests. I sought to examine the often contradictory roles public space plays in urban politics and economics, the functions it serves for the housed and unhoused, and the degree it aids or does not aid in the formation of publics and counterpublics. I understood these to be questions of law as well as practice, rights as well as custom, policing as well as protest. Thus, they were questions of the relationship between public and private, the domestic and the civic, and the structures of inclusion and exclusion. They were questions of who owns public space as well as who controls it. They were questions of the ends of public space, as well as the means. I was quite explicit in my conclusion: "Arguments in behalf of the thesis of "the end of public space", I wrote

suggest that an orderly, controlled vision of public space is squeezing out other ways of imagining public spaces. The recent history of People's Park suggests that these arguments are, if profoundly important, too simple. Oppositional movements continually strive to assure the currency of more expansive visions of public space. Still, to the degree that the 'disneyfication' of public space advances and political movements are shut out of public space, oppositional movements lose the space where they may be represented (or may represent themselves) as legitimate parts of 'the public.' As the words and actions of the protagonists in Berkeley suggest, the stakes are high and the struggles over them might very well be bloody. But that is at once the promise and the danger of public space" (pages 127-128). 
Yet much, and perhaps over time most, of the public space research that has made up the tidal wave has been in opposition, sometimes explicitly sometimes implicitly, to narratives about 'the end of public space', often hollowing them out by assuming that 'the end of public space' is taken by writers and researchers like Davis, Sorkin's contributors, or myself as a given, a fact, a full description of the historical-geographical moment, rather than as a dialectical proposition meant to be examined materially (as in the conclusion quoted above) or even a hypothesis to be tested (eg, Lees, 1998; Paddison and Sharp, 2007). ${ }^{4}$

There is a cost to this opposition to and dismissal of the end of public space proposition. Important questions, like the ones laid out above about what public space is in capitalist cities have too often been sidelined, as scholars have sought to show what it is not - that it is not a space of simple control, for example, or that it is not a material site (but rather an immanent production that comes into being through momentary practice). Ignoring the ways in which the end of public space is always a tendency (though definitely a contradictory one) within capitalist urban economies leads to a too-easy set of assumptions about possibilities for cosmopolitan or egalitarian encounters in urban space rather than an analysis of the constraints that might make such encounters unlikely. It often leads to an untenable idealism that assumes the rather full malleability of space (as well as the irrelevance of law, the state, or property owners to shape that space). It risks being unable to understand how the tendency towards the end of public space (and opposition to that tendency) shapes the ends of public space, historically, in the present, and in the future. The end of public space is, in other words, an ongoing history.

\section{Three struggles in the ongoing history of the end of public space}

By exploring three moments of intense use of and struggle over public space in Oakland and Berkeley, California, I would like in what follows to revive the question of the end - and the ends - of public space and to examine its ongoing, perhaps never-ending history. By focusing on the structuring, control, and use of actually-existing spaces so as to raise again the question of public space's promise, as well as its danger, I will show that the issues that sparked the boom in public space research in the first place - both the scholarly and the social issues - have hardly gone away. Instead, they have led to new questions, perhaps in surprising ways, about the production of, and struggle against, abstract space in the capitalist city.

\section{Occupy Oakland}

Unlike Occupy Wall Street, Occupy Oakland occupied a public public space. Oakland's Frank Ogawa Plaza in front of City Hall was designed and built in the 1990s as a public space for political assembly, surrounded by a park to be used by nearby Single Room Occupancy (SRO) residents and office workers, much of it developed, it seems, on the terms of good public space design that William H Whyte (1980) long promoted. The park's designer, Michael Pyotok, understood Ogawa Plaza itself to be:

the 'front yard' of city hall. As such it was expected to host a variety of public events: cultural performances, festivals, campaign speeches, important public announcements, ceremonies and celebrations. This, of course, included expected protests and demonstrations, not just about local issues, but also those affecting the nation as a whole, so crowds at times could be large" (2012, pages 316-317).

The design team thus created the plaza as an amphitheater - a forum - with a natural stage, seating spread around, and plenty of room on the lawn for larger gatherings. While speakers, 
with their backs to City Hall addressed the crowd, the crowd directly faced and addressed City Hall.

If other architects writing in the book from which I just quoted Pyotok-Beyond Zuccotti Park (Shiffman et al., 2012) — complained that 'their' public space designs had been hijacked by various Occupations, Pyotok was thrilled by the occupation of Frank Ogawa Plaza. He noted that, while other East Bay cities had plazas suitable for protest, "none host[ed] a parklike setting as well." The "convenient combination of park and plaza became simultaneously a 'domestic' and civic setting: the soft carpeted park - the people's mattress - became the bedroom and the paved forum became the formal living room" (Pyotok, 2012: 319). Moreover, the various small seating areas designed with the needs of SRO residents and office workers in mind provided space for the small group meetings that were such an integral part of the Occupy structure. Pyotok saw the park and plaza as a perfect venue for making public both the broad grievances of the global Occupy movement and the more specific grievances of Oakland and the East Bay.

When they won the competition to design the park and plaza, Pyotok and his firm were not known for public space design. Rather, they specialized in subsidized housing developments. "We could foresee none of these events" that marked Occupy Oakland, Pyotok (2012: 322) says. But "by following our instincts as housing designers, we took into consideration the open space needs for everyday activities and for those special events that take place in domestic settings and made an effort to include communal versions of these things at the doorsteps of Oakland City Hall." The result was to create, remarkably, a public space that functioned - and could be occupied, that is lived in - as a public space. The Oakland government's just as remarkably confused response to Occupy Oakland provided quite definitive proof of just how successful this making public (through the occupation of a space designed to be domestic) of public space was. So does the remarkably violent suppression of Occupy Oakland when it finally came, a suppression that in the end seemed to deny the very reason for (and design of) Frank Ogawa Plaza and its surrounding park: public space had been put to an end, a political end, by its Occupiers; public space was put to a different kind of end-more or less eliminated as a political force - by the police. This is how struggles that make, and destroy, actually-existing public space unfold. This is how the tendency towards the end of public space plays out. ${ }^{5}$

\section{Berkeley's sit-lie law}

In November 2012, a year after the Occupy Oakland encampment was destroyed, the residents of neighboring Berkeley were asked to consider - not for the first time - a ballot initiative that would have created a new sit-lie law. ${ }^{6}$ The "Berkeley Civil Sidewalks Initiative"-Measure S-like so many of its brethren around the country sought to outlaw sitting or lying on sidewalks between the hours of $7 \mathrm{am}$ and $10 \mathrm{pm}$ in districts zoned commercial, except in cases of medical emergency, or someone sitting in a wheelchair, on a permanent public bench or bus stop, at a street event for which a permit had been received, or in outdoor café seating. Violators would be subject to a US \$75 fine (or community service) for a first offence; subsequent offices could be charged as misdemeanors. Before citations could be issued, police would be required to issue a warning and the offender given a chance to desist; warnings were to be effective for thirty days (City Attorney, 2012).

Supporters of the law (including the mayor and some councilmembers, various merchants associations, and an organization called Livable Berkeley) argued that such laws had proven effective in more than sixty US cities and that Berkeley was being asked to consider it now only because all previous efforts in what they called a "humanitarian city" had failed to 
dissuade the formation of what they termed "street encampments" nor to disperse those who "resist our help" (Arguments in Favor, 2012). The initiative itself declared in its findings that:

Public spaces in commercial areas have become increasingly inhospitable due to groups of individuals, often with dogs, having created encampments on sidewalk areas on our commercial streets. The encampments obstruct pedestrian access, and result in litter, debris, and waste left on our sidewalks" (Text of Measure, 2012, §1B).

Moreover, "City parks are open and available during the day for everyone's use" (Text of Measure, §1C). If passed, the measure would not come into effect until July 2013 to give time for outreach workers - who were really BID-paid 'ambassadors' and not social workers or other professionals - to educate street populations about the new law before it was enforced. For that reason, advocates argued, a primary purpose of Measure S was to "help people get social services" as well as to "help merchants grow local jobs, and ensure civil and welcoming sidewalks for everyone" (Arguments in Favor, 2012).

Opponents (who included other councilmembers, some merchants, the American Civil Liberties Union, the University of California student government, and various interest groups) noted that there were four homeless people in Berkeley for every shelter bed and that the shelter shortage was especially acute for homeless youth - the population that seemed most directly targeted by the initiative. They argued that the 'ambassadors' were not trained in mental health or homeless outreach. They noted that a San Francisco City Controller's report had found that city's law-upon which the Berkeley initiative was based - had "failed 'to improve merchant corridors, serve as a useful tool for SFPD [San Francisco Police Department], connect serviced to those who violate the law, and positively contribute to public safety"' (Rebuttal to Argument in Favor, 2012). They questioned how criminalizing sitting on sidewalks would, as advocates asserted, "help homeless people get the critical services they NEED to transform their lives" (Rebuttal to Argument Against, 2012). Regarding the text of the law, a columnist for the online Berkeley Daily Planet wrote:

Fortunately for me, I'll get an exemption for sitting on the sidewalk under the shade of a nice tree or building - I get to sit in my wheelchair and won't be bothered. I will, however, continue to be inconvenienced by the growing number of café and restaurant owners who have annexed the 'public' sidewalks with their sprawling tables and chairs.... At least the good folks sitting on the sidewalk will move out of my path-of-travel when asked (most times I needn't bother to even ask - but those darned tables and chairs refuse to move even an inch!)" (Pachovas, 2012).

Though proponents of the law outspent opponents by a factor of 10-1, Berkeley residents rejected it $52 \%$ to $48 \%$. It was the first time since 1994 that voters in any city in the US rejected a ballot initiative "criminalizing homelessness" (Messman-Rucker, 2012), which, the head of the Telegraph BID warned, would "attract more loiterers to Berkeley's sidewalks". The BID and its counterparts in other districts nonetheless conceded defeat on this front and turned their attention to launching a redevelopment program aimed at street redesign that would make Telegraph and downtown's Shattuck Avenue more welcoming to middleincome and upper-income consumers and less welcoming to the destitute (Kearney, 2012).

Like the events at Ogawa Park, the fight over Measure S was a fight over the ends of public space. For a minority of voters - at least if the arguments in favor of Measure S are representative of their views - public space needs to be cleared of undesirable people, especially those "who resist our help". Cleanliness and order trump 'being' in space. Public space is public space only to the degree that it is made easy to move through and cleared of unsightly 'encampments'. A majority of voters, however, seemed to recognize that 
one end of public spaces like sidewalks is to provide a place for homeless and other destitute people to sit, maybe even hang out. It is a place where all people can be, regardless of their means (unlike in the encroaching cafés). If the end of public space is a tendency, then sometimes that tendency is thwarted by people acting democratically.

\section{People's Park (again)}

Another place where homeless and other destitute people hang out in Berkeley is People's Park. It has served this end since it was first created in spring 1969. Many people in Berkeley, with some degree of justification, do not think People's Park is a safe space. Its status as a refuge for the destitute is certainly not safe, and never has been. At dawn on 28 December 2011, not long after Occupy encampments were cleared out of most US cities, and when students were not in class and many housed people were enjoying the holidays, UC sent bulldozers into the park. Unlike other such moves in the past, this one met no resistance. The move was focused on the west end of the park, behind the Free Stage, an area of community gardens, tall trees, and winding paths. The bulldozers and crews ripped up the gardens which dated from 1979 when activists themselves ripped up a small asphalt parking lot UC had built on the site. They also knocked down the trees, some of which predated the park. And they destroyed a pergola, which had been built out of the net-posts of the volleyball courts UC built at the time of the 1991 riots, but which it abandoned only a few years later (Fonseca, 2012; Yu, 2011).

Describing its actions as "routine heavy park maintenance", UC argued it had to remove the pergola because it was "heavily covered in vegetation" (Gilmore, 2011). ${ }^{7}$ Even though it destroyed the community gardens, UC said "the overall look of the park itself will not change - the stage, the benches, the community gardens and other features will remain intact." By intact, UC seemed to mean that the community gardens would be replaced with "seedlings for smaller plants that consume little water and are decorative" (Gilmore, 2011). The tall trees were removed to improve views for students moving into a soon-to-becompleted dorm across the street (Denny, 2011). Perhaps the most symbolic destruction was of the "Council Grove", a circle of trees that served as the site for many People's Park Council meetings in the early 1970s where questions of user-control and user-design were debated. The current, anemic, iteration of the council, the People's Park Community Advisory Board - an organization UC created and is bound by its own agreements to consult with - was not informed of the 'heavy maintenance', learning of it only as park users saw the equipment arrive and UC issued a simultaneous press release.

The lack of mobilization against this move by UC suggests, perhaps, that (as many argue) after more than four decades of struggle and stasis, People's Park is ripe for change. The Telegraph Avenue BID certainly thinks so. In August 2011 it had sent a letter to UC laying out a set of recommendations for the redevelopment of People's Park, which, it hoped, would turn it into an asset for nearby businesses rather than continue as "a haven for drug dealing, drug and alcohol abuse and the various antisocial and criminal behaviors they induce", a function that has persisted, the BID asserted, only because of "a cadre of activists who zealously protect the status quo." As the bulldozers were still at work, the president of the BID indicated this was the beginning of the implementation of its recommendations (Cruz, 2012; Paterson, 2012).

In fact, a park activist, using various open records requests, discovered UC spent $\$ 12000$ on this first round of 'heavy maintenance' and had plans to spend more than $\$ 200000$ more on another two phases of park improvement (at a time of ongoing cuts in UC budgets). UC has steadfastly refused to make its plans clear (O'Malley, 2012). ${ }^{8}$ Many think the December 
2011 operation was a first, highly attenuated, effort to begin to act on recommendations made in 2007 by the San Francisco design consultants MKThink.

Working with UC as well as the Community Advisory Board, MKThink produced a draft plan for park redevelopment. A starting proposition for MKThink (2007, page 5) was that "In its current state, the delivery in the park of food and social services for at-risk populations is incompatible with the broad objective of making this space enjoyable for community members." The 'at-risk' population was understood by the design firm as having little (positive) agency of its own. Rather MKThink (2007: 5) asserted that this population needed to be dealt with through "professionally-administrated comprehensive care" which would "provid[e] self-empowerment skills and medical care". People's Park, the consultants argued, did not have, and could not conceivable have, the facilities to make such care possible (even though hundreds of meals a week are served in the park, largely through mutual aid priniples). MKThink (2007: 5) argued instead that removing homeless and other indigent people from the park while remembering and memorializing the park's history would help the space "form an identity around humanistic values".

The problem with People's Park, according to MKThink (2007: 11) was that, unlike almost all other parks, it "had never benefited from a formal design and planning process". The draft report sought to remedy this shortcoming. To that end, MKThink sought to align design means with what it understood to be the proper ends of a public space like People's Park. One design suggestion was therefore to rework the southwestern corner of the park (where UC began its maintenance in December 2011) into a hardscaped "commons" of about a tenth of an acre (MKThink, 2007: 29). The copy of the draft plan I found had been annotated by a park activist. The activist wrote here: "The whole Park is now the "commons", , suggesting a rather different vision of what kind of public space People's Park is and ought to be than that proposed by MKThink. This difference is deepest in MKThink's plans to fill the park with "programming"-design features meant to allow for or encourage highly specific activities. The end of public space, in this view, is to provide a space for programming, for "special events and recreational activities", for "University-sponsored events" as well as for "theatrical performances, poetry readings, art installations, farmer's markets, and outdoor workshops" (MKThink, 2007: 6). In MKThink's view, occupation of space by poor people without homes or other places to hang out (a traditional function of People's Park), or for the provision of free meals to these same people, did not constitute appropriate programming. Commonly produced space-a space taken and made a commons, with (as with People's Park) use-rights, and therefore bases for exclusion, reasonably well understood - was not a properly public space, a space "enjoyable and welcoming for all community members".

\section{Public space/abstract space}

Public space is a struggle. And these three stories provide a glimpse into what that struggle looks like on the ground. It is varied, piecemeal, and never ending (none of these stories has a conclusion - an end). But, really, to what end are these struggles engaged? There are local answers to this question, of course: some merchants and city officials in Berkeley want to reorder their streets such that the presence of street people is minimized, while activists and other merchants and officials seek to keep them open as a place where the destitute can hang out. Other activists grab hold of public spaces like Frank Ogawa Plaza to publicize - literally - a set of claims about inequalities and oppressions of the world we live in and in the process experiment with making new forms of life in public. Back in Berkeley, UC has long wanted to either eliminate People's Park altogether or remake it as 
a quite different kind of public space, one in which programming especially for students is paramount, while 'Park Defenders' have sought to retain it as a free space - a commons - that stands at least in partial opposition to the alienating landscapes of the contemporary capitalist city.

But there are more global answers too. At this point one could turn (and many have including myself) to Henri Lefebvre (1991) and his famous spatial triad to suggest there is an ongoing struggle, a dialectic, between efforts to implant representations of space (ordered, planned, controlled space) and representational space (appropriated, lived space) as mediated by spatial practices. Such an analysis would show how actually-existing public space emerges from this ongoing dialectic as well as how struggles and compromises at one moment set the stage - literally, by producing the material, concrete form of the space-for struggles and compromises at the next moment. In this sense public space is not the "phantom public sphere" (Robbins, 1993) but the very place where the public sphere comes into being, as such. This is as true of the publics that are formed and recognized in a mall as it is of those that formed and were recognized during Occupy Oakland (cf Staeheli and Mitchell, 2008). The ends of public space, in this argument, are to become spaces for representation, spaces of and for the appearance of the public (or publics). The end of public space - in the sense of its elimination - is the thwarting or overlimiting or total scripting of possibilities for self-forming publics to appear, to represent themselves, to be represented. The streets of Berkeley, as well as People's Park, are places where alternative publics, maybe what could be called 'street publics', form and are recognized (for better and for worse). Streets and parks are places where homeless and other street people can be seen and recognized.

So that is one way that turning to Lefebvre's insights on the production of space might help us understand the dialectic of the end and ends of public space, and it is an important way. But there is another, more 'abstract', but nonetheless important tale to tell. I have asserted that the end of public space (end in the sense of closing down, controlling, enrolling space in the process of capital accumulation) is always a tendency in capitalism. This tendency has another name: the tendency and necessity of capitalism to produce abstract space. "We already know several things about abstract space", Lefebvre (1991: 285) wrote:

As a product of violence and war, it is political; instituted by the state, it is institutional. On first inspection it appears homogenous; and indeed it serves those forces which make a tabula rasa or whatever stands in their way, of whatever threatens them - in short of differences. These forces seem to grind down and crush everything before them, with space forming the function of a plane, a bulldozer or a tank. The notion of the instrumental homogeneity of space, however, is illusory...."

Instead: "Abstract space is not homogenous; it simply has homogeneity as its goal; its orientation, its 'lens'. ... But in itself it is multiform" (Lefebvre, 1991: 287).

What then is 'abstract space', this 'multiform tendency' that is not homogenous? Though it predates capitalism (as the reference to war and the state indicate) capitalist abstract space is the spatial equivalent of Marx's abstract labor (Lefebvre, 1991: 307). Abstract labor is labor abstracted out of its specific, decidedly nonhomogenous forms, and made commensurable. The concept 'abstract labor', as well as the actual practices it represents, lets us begin to see how, in practice, specific, qualitatively different labors are made equivalent to each other. Abstract space is similarly "a medium of exchange (with the necessary implication of interchangeability) tending to absorb use" (Lefebvre, 1991: 307), which is to say, it is capitalist space.

The production of abstract space-or the constant attempt to produce abstract space despite all the spatial practices that will seek to produce it otherwise - is a capitalist necessity. 
This is to say that space in capitalism must be produced so as to be commensurable, so as to be abstractable and therefore exchangeable. Use must be 'absorbed' into exchange, with the latter dominant. ${ }^{9}$ Lefebvre no doubt overstates the case [since abstract space is a tendency as much as it is a necessity, and also because as Harvey $(1982,2001)$ has shown time and again, the capitalist production of space is deeply contradictory], but his general point is correct: "Existing property and production relations... shatter conceptions of space that tend to form in dreams, in imaginings, in utopias or in science fiction" (Lefebvre, 1991: 357). Only alternative practice - practice that remakes space against, or in spite of, or within capitalist abstract space - can create a different kind of space (and must do so if life, or for that matter capitalism, is to survive). ${ }^{10}$ In this sense:

Today more than ever, the class struggle is inscribed in space. Indeed, it is that struggle alone which prevents abstract space from taking over the whole planet and papering over all differences. Only the class struggle has the capacity to differentiate, to generate differences which are not intrinsic to economic growth qua strategy, 'logic,' or 'system' - that is to say, differences which are neither induced by nor acceptable to that growth. The forms of class struggle are now more varied than formerly. Naturally, they include the political action of minorities" (Lefebvre, 1991: 55).

Frank Ogawa Plaza was designed and developed as part of a strategy to remake Oakland's floundering downtown. Actively disinvested beginning in the 1950s (Oakland was especially hard-hit by white flight), and largely by-passed by the Bay Area's silicon-tech boom (until very recently), Oakland redeveloped the City Hall area as an attempt to recommoditize its landscape, to produce the city as an abstract space open for investment and accumulation. Frank Ogawa Plaza was a particular place within this strategy, and Michael Pyotok and associates were certainly constrained in their designs by that fact. (Their decision to retain space for remaining SRO residents is all the more admirable for this reason.) But then during Occupy, Ogawa Plaza and the surrounding park were taken and made into something else; they became spaces not only within which new publics could recognize themselves, but from which a larger assault on the abstraction of space (and the logics behind it - the logics of accumulation) could be launched. The area in front of City Hall became a center from which differential space (as Lefebvre calls it) could be produced and the capitalist abstraction of spaces could be contested. ${ }^{11}$ The tendency towards the end of public space - the tendency towards the abstraction of space-was interrupted by putting a particular public space to a different end (though not one entirely different from that intended by its designers, interestingly enough).

Which is to say: while abstract space is a production, it is also something that has to be maintained and policed. If one tendency is towards the production of abstract space, which includes the end of public space, then another tendency is always towards spaces' use. Just as abstract labor has to be enforced-socially necessary labor time is not natural, but the result of work (the work of foremen, managers, engineers, time-motion specialists, etc) - so too does abstract space, the end of public space, have to be enforced and managed, both of which require considerable work. Ballot initiatives have to be composed and signatures gathered. Police forces have to be organized and plans to clear out and retake public spaces have to be made and put into action. Jails have to be readied. Public relations officers have to be briefed. Laws have to be written. Designs have to be drawn up and bulldozers and construction crews set to work. At each of these moments, in each step of this making and reinforcing abstract space, opposition - or even just other ways of being in space - can arise. If they are not accounted for, if they are not managed, then they might just change what public space is. New differential spaces might arise, as with the original building 
and defense of People's Park and, perhaps more temporarily, with Occupy Oakland. Such differential space must be reclaimed and remade if the tendency towards abstract space is to be fulfilled, which accounts for the ferocity of police reaction when it comes: it is a reassertion of space as abstract space.

Similarly, at stake in Measure $\mathrm{S}$ was what kind of space, what degree of exchangeability and commensurability, the streets of Berkeley were to be. The proposition was an attempt to manage all the contradictory forces that arise when the tendency towards abstract space advances in the capitalist city. And the plans of UC and MKThink to subject People's Park to a formal design process and fill it with programming, was likewise an attempt to manage the abstraction of space, to help assure that the exchangeability of space 'absorbs use'. Uses of these spaces - turning the lawn around Frank Ogawa Plaza into 'the people's mattress' as well as a protest site, street people hanging out and finding allies in many city voters, and activists, residents, and organizations seeking to retain Peoples Park as a commons - make such assurance only aver a tendency, never a complete actuality. Public space is a struggle. In this struggle, public space comes to be in its material actuality — as a site, a place - and in coming to be it sets the bounds also for what the public can be.

\section{Conclusion}

Here we return to right where we started, to the question of the ends of public space. It is a question that has not gone away in all the years People's Park has existed and been fought over, nor in all the years and all the studies that have mushroomed in geography since the early 1990s. Indeed, it is not too much of a stretch to say that much, probably most, of that work has been about specifying the nature of the struggle, and the work of managing the struggle, between abstract space and differentiated space, between public space in which exchange dominates use and public space in which it does not (even if this is not how these studies have been named). The question of the end and ends of public space has not gone away because the tendency towards the end of public space in capitalism has not gone away, and cannot. Continuing to figure out why not, and how not, remains a vital task for urban scholars and activists alike. Doing so will help us better understand that public space is always a struggle, and a necessary one.

\section{Declaration of conflicting interests}

The author(s) declared no potential conflicts of interest with respect to the research, authorship, and/or publication of this article.

\section{Funding}

The author(s) received no financial support for the research, authorship, and/or publication of this article.

\section{Notes}

1. As part of the research that culminated in The People's Property, Staeheli and Mitchell (2008) collected every piece on public space identifiably written by geographers or published in geographical outlets between 1946 and 1998. The accounting in this paragraph draws on this research. 
2. I searched on "public space" (as a phrase) for each specific year and counted only those items appearing in geography journals or by authors who were easily identified as geographers. In Scopus, book chapters and books typically do not appear.

3. After the 1999 Seattle World Trade Organization protests, the negotiated management strategy began to give way to what Vitale (2005) calls a "command and control" model.

4. For a quite nuanced assessment of the arguments, however, see Madden (2009). Belina (2011/12) takes a different tack. He argues for "ending" public space as a useful conceptual and political category since it is so easily coopted by forces of urban order and privilege. But, though Belina calls for a more materialist approach to research on urban exclusion, his argument operates only at the level of ideology. It fails to examine closely enough the structuring forces at work in spaces-assites themselves. In other words, he does not pay enough attention to the dialectic between ideology on the one hand and the use and structuring of spaces on the other.

5. A reviewer urges me to recognize that the case of Occupy Oakland is more ambiguous than I seem to let on. This reviewer points out that "Occupy Oakland crumbled in part due to the difficulties involved in absorbing a population [the homeless population produced and unserved by the neoliberal order] with concerns very different from those of the activists." I largely agree that this was a cause of Occupy's collapse (and not only in Oakland), though I am not convinced that homeless peoples' and activists' "concerns" were necessarily very different. But none of this matters to the story I tell above, which is about the design of public space, what the intents of that design were, and how the space was subsequently expropriated in Occupy. It is not about the successes and failure of the Occupy movement. I address the question of the degree to which Occupy was able to 'absorb' the homeless in their movement in Mitchell (2014).

6. Small portions of this and the next case are told in Mitchell (2014).

7. The irony was lost on few.

8. And in the three years since the 'heavy maintenance' no other work seems to have been undertaken.

9. Of course, 'abstract space' no more wears a label marking its presence than does 'value' (the material form of abstract labor). Value - abstract labor congealed-takes form in specific (commensurable) commodities; abstract space takes form in specific-potentially commensurable-places, as the next sentences suggest.

10. As Smith (1990) showed in a broader context, capitalism must always negotiate between two competing tendencies: towards equalization on the one hand and differentiation on the other. This negotiation is the fulcrum of uneven capitalist development. The tendency towards abstract space and the struggle for differential space are material instances of these broader tendencies.

11. The short-term or long-term success of this contestation is another matter.

\section{References}

Arguments in Favor (2012) Argument in favor of measure S. Available at: www.ci.berkeley.ca.us/ Clerk/Elections/Election_2012_Ballot_Measure_Page.aspx (accessed 1 October 2015).

Belina B (2011/12) Ending public space as we know it. Social Justice 38(1/2)): 12-26.

City Attorney (2012) City attorney's impartial analysis. Available at: www.ci.berkeley.ca.us/Clerk/ Elections/Election_2012_Ballot_Measure_Page.aspx (accessed 1 October 2015).

Crilley D (1993) Megastructures and urban change: Aesthetics, ideology and design. In: Knox P (ed.) The Restless Urban Landscape. Englewood Cliffs, NJ: Prentice-Hall, pp. 126-164.

Cruz K (2012) Business owners recommend changes to People's Park. The Daily Californian, 31 August.

Davis M (1990) City of Quartz: Excavating the Future in Los Angeles. New York, NY: Verso.

Denny C (2011) Flash: UC Berkeley bulldozes people's park to make it more 'sanitary'. The Berkeley Daily Planet, 28 December.

Fonseca A (2012) UC Berkeley officials desecrated people's park. Street Spirit, 3 February.

Gilmore J (2011) People's park maintenance work underway. 28 December. Available at: http:// newscenter.berkeley.edu/2011/12/28/peoples-park-maintenance-work-underway/_ (accessed 1 October 2015). 
Goss J (1996) Disquiet on the waterfront: reflections on nostalgia and utopia in the urban archetypes of festival marketplaces. Urban Geography 17: 227-247.

Harvey D (1982) The Limits to Capital. Chicago, IL: University of Chicago Press.

Harvey D (1987) Flexible accumulation through urbanization: Reflections on postmodernism in the American city. Antipode 19: 1-42.

Harvey D (1989a) From managerialism to entrepreneurialism: The transformation of urban governance in late capitalism. Geografiska Annaler B 71: 3-17.

Harvey D (1989b) The Condition of Postmodernity. Oxford: Blackwell.

Harvey D (2001) Spaces of Capital. New York, NY: Routledge.

Hopper K (2003) Reckoning with Homelessness. Ithaca, NY: Cornell University Press.

Katz C (2006) Power, space, and terror: social reproduction and the public environment. In: Low S and Smith N (eds) The Politics of Public Space. New York, NY: Routledge, pp. 105-122.

Kayden J (2000) Privately-owned Public Space: The New York Experience. New York, NY: Municipal Art Society of New York.

Kearney L (2012) Measure S campaign anticipates loss, looks at next steps. Berkeley Patch, 13 November.

Kohn M (2004) Brave New Neighborhoods: The Privatization of Public Space. New York, NY: Routledge.

Lee S (Dir.) (1989) Do the Right Thing. 40 Acres \& A Mule Filmworks. .

Lees L (1998) Urban renaissance and the street: Spaces of control and contestation. In: Fyfe N (ed.) Images of the Street: Planning, Identity, and Control in Public Space. London: Routledge, pp. 236-253.

Lefebvre H (1991) The Production of Space. Oxford: Blackwell.

McPhail C, Schweingruber D and McCarthy J (1998) Policing protest in the United States: 1960-1995. In: Della Porta D and Reiter H (eds) Policing Protest: The Control of Mass Demonstrations in Western Democracies. Minneapolis, MN: University of Minnesota Press, pp. 49-69.

Madden D (2009) Revisiting the end of public space: Assembling the public in an urban park. City and Community 9: 187-207.

Marston S (1990) 'Who are the people'? Gender, citizenship, and the making of the American nation. Environment and Planning D: Society and Space 8: 449-458.

Messman-Rucker A (2012) Berkeley chooses compassion: Measure S rejected by voters. Street Spirit, 5 December.

Miller K (2007) Designs on the Public: The Private Lives of New York's Public Spaces. Minneapolis, MN: University of Minnesota Press.

Mitchell D (1995) The end of public space? People's Park, definitions of the public, and democracy. Annals of the Association of American Geographers 85: 108-133.

Mitchell D (2014) Postscript to the 2014 edition. The Right to the City: Social Justice and the Fight for Public Space. New York, NY: Guilford.

MKThink (2007) People's park assessment and planning study, draft summary report, October 1. Available at: www.peoplespark.org/mkthink/mkthink-draft-proposal.pdf (accessed 1 October 2015).

Németh J (2009) Defining a public: The management of privately owned public space. Urban Studies 46: $2463-2490$.

Newman O (1972) Defensible Space: Crime Prevention through Urban Design. New York, NY: Macmillan.

O'Malley B (2012) Can UC Berkeley be saved from another people's park debacle? The Berkeley Daily Planet, 2 March.

Pachovas M (2012) Berkeley's asinine sitting ban measure. Berkeley Daily Planet, 19 October.

Paddison R and Sharp J (2007) Questioning the end of public space: Reclaiming control of local banal spaces. Scottish Geographical Journal 123: 87-106.

Paterson R (2012) UC must transform people's park's legacy. The Daily Californian, 3 February.

Pyotok M (2012) When domestic space meets civic space: A case for design populism. In: Shiffman R, Bell R, Brown L and Elizabeth L (eds) Beyond Zuccotti Park: Freedom of Assembly and the Occupation of Public Space. Oakland, CA: New Village Press, pp. 309-326. 
Rebuttal to Argument Against (2012) Rebuttal to argument against ballot measure S. Available at: www.ci.berkeley.ca.us/Clerk/Elections/Election_2012_Ballot_Measure_ Page.aspx (accessed 1 October 2015).

Rebuttal to Argument in Favor (2012) Rebuttal to argument in favor of measure S. Available at: www.ci.berkeley.ca.us/Clerk/Elections/Election_2012_Ballot_Measure_ Page.aspx (accessed 1 October 2015).

Robbins B (ed) (1993) The Phantom Public Sphere. Minneapolis, MN: University of Minnesota Press.

Shiffman R, Bell R, Brown L, et al. (eds) (2012) Beyond Zuccotti Park: Freedom of Assembly and the Occupation of Public Space. Oakland, CA: New Village Press.

Smith N (1989) Tompkins square park. The Portable Lower East Side 6(2): 1-28.

Smith N (1990) Uneven Development: Nature, Capital and the Production of Space, 2nd ed. Oxford: Blackwell.

Soja E (1989) Postmodern Geography. Oxford: Blackwell.

Sorkin M (ed) (1992) Variations on a Theme Park: The New American City and the End of Public Space. New York, NY: Hill and Wang.

Staeheli L and Mitchell D (2008) The People's Property? Power, Politics, and the Public. New York, NY: Routledge.

Text of Measure (2012) An ordinance of the city of Berkeley adopting a new section 13.36.025 of the Berkeley municipal code to prohibit sitting on sidewalks in commercial districts. Available at: www.ci.berkeley.ca.us/Clerk/Elections/Election_2012_Ballot_Measure_ Page.aspx (accessed 1 October 2015).

Vitale A (2005) From negotiated management to command and control: how the New York police DEPARTMENT polices protests. Policing and Society 15: 283-304.

Waldron J (1991) Homelessness and the issue of freedom. UCLA Law Review 39: 295-324.

Whyte W (1980) The Social Life of Small Urban Spaces. Washington, DC: The Conservation Society.

Whyte W (1988) City: Rediscovering the Center. New York, NY: Doubleday.

Wilson J and Kelling G (1982) Broken windows: the police and neighborhood safety. Atlantic Monthly March, 29-38.

Yu J (2011) Contentious maintenance project begins at people's park. Daily Californian, 31 December. Zukin S (1995) The Cultures of Cities. Oxford: Blackwell. 